\title{
STRATEGI PRODUKSI PUPUK ORGANIK CAIR KOMERSIAL DARI LIMBAH RUMAH POTONG HEWAN (RPH) SEMARANG
}

\author{
Wiharyanto Oktiawan ${ }^{1}$, Anik Sarminingsih ${ }^{2}$, Purwono $^{3}$, Mahfud Afandi ${ }^{4}$ \\ ${ }^{1,2,3}$ Dosen Program Studi Teknik Lingkungan Fakultas Teknik Universitas Diponegoro \\ ${ }^{4}$ Mahasiswa Teknik Lingkungan Fakultas Teknik Universitas Diponegoro \\ JL. Prof. H. Sudarto, SH Tembalang Semarang, Indonesia 50275 \\ email: w_oktiawan@yahoo.com
}

\begin{abstract}
Abstrak
Limbah Rumah Pemotongan Hewan (RPH) Kota Semarang yang didominasi oleh rumen sapi jika tidak diolah dapat menyebabkan ketidaknyamanan pada manusia dan kerusakan lingkungan. Dampak negatif dari limbah adalah proses pembuangan dan pembersihannya memerlukan biaya serta efeknya dapat mencemari lingkungan. Hal ini mendorong adanya inovasi dan pengembangan teknologi pengolahan air limbah yang murah dan mudah operasional dan pemeliharaannya serta biaya yang sedikit. Upaya meningkatkan keuntungan akan keberadaan limbah dilakukan cara mengolah limbah menjadi produk yang bermanfaat dan bernilai jual. Keuntungan yang bisa diperoleh dari proses pengolahan limbah tersebut menjadi biogas, bioenergi, dan pupuk. Pupuk yang mengandung magnesium yang tinggi yang beredar di pasaran biasanya berbentuk granull serbuk. Apabila tanaman mengalami kekurangan magnesium maka akan menyebabkan kuningnya daun dan menghambat proses fotosintesis yang terjadi di daun.

Penambahan limbah garam pada penelitian ini diharapkan dapat meningkatkan kandungan unsur hara makro $C, N, P, K$, dan Mg, tidak mencemari lingkungan, tidak merusak struktur tanah, serta mudah dalam pengaplikasiannya. Variasi rasio serat kasar dengan cairan rumen bertujuan untuk mengetahui kandungan paling optimum, antara lain: 100:0 ,75:25 , 50:50 , 25:75 , 0:100 (serat kasar:cairan rumen). Hasil penelitian menunjukan bahwa penambahan limbah garam tidak mempengaruhi terhadap kandungan unsur hara C-Organik dan Nitrogen, sedangkan pada kandungan Fospor, Kalium, dan Magnesium memiliki pengaruh dari penambahan limbah garam. Kandungan unsur hara makro paling optimum yaitu C-Organik pada fermentor B1 sebesar 1,44\%, Ntotal pada fermentor B2 sebesar 0,73\%, Fospor (P2O5) pada fermentor B3 sebesar 2,243\%, Kalium pada fermentor B3 sebesar 13,05, dan Mg pada fermentor B3 sebesar 26,82\%. Meskipun demikian, pupuk organik cair ini belum memenuhi persyaratan teknis Permentan No.70/Permentan/SR.140/10/2011 tentang pupuk organik, pupuk hayati dan pembenah tanah.
\end{abstract}

Kata Kunci : Pupuk Organik Cair, Limbah Rumen, Limbah Garam, Magnesium.

\section{PENDAHULUAN}

Semakin berkembangnya industri maka meningkat pula kebutuhan manusia. Terutama untuk penyediaan daging sapi sebagai kebutuhan manusia. Rumah Pemotongan Hewan, setiap harinya menyediakan daging segar yang didistribusikan ke pasar-pasar di Kota Semarang untuk memenuhi kebutuhan manusia. Dari kegiatan pemotongan sapi ini menghasilkan produk samping berupa limbah. Limbah ini apabila hanya didiamkan menyebabkan ketidaknyamanan pada manusia dan kerusakan lingkungan. Menurut Djaja (2008) dampak negatif dari limbah adalah proses pembuangan dan pembersihannya memerlukan biaya serta efeknya dapat mencemari lingkungan. Oleh karena itu, limbah yang berasal dari bahan organik dapat dimanfaatkan kembali menjadi produk yang memiliki nilai ekonomis.

Limbah dari Rumah Pemotongan Hewan (RPH) Kota Semarang pada peninjauan sebelumnya belum dilakukan pengolahan secara optimal. Dikarenakan proses pembuatan instalasi pengolahan air limbah (IPAL) dan pemeliharaannya membutuhkan waktu serta biaya yang banyak. Menurut Roihatin dan Arina (2010) menyatakan bahwa apabila limbah tidak dilakukan pengelolaan dan/atau pengolahan pada limbah RPH maka limbah tersebut menjadi media pertumbuhan dan perkembangan mikroba sehingga limbah mengalami pembusukan. Limbah RPH berupa feses, urine, isi rumen atau 
isi lambung, darah afkiran daging atau lemak, dan air cuciannya.

Isi Rumen Sapi (IRS) dibagi menjadi 2 bentuk yaitu padat dan cair. Isi Rumen Sapi padat berupa bagian kasaran dari rerumputan yang telah dicerna oleh sapi. Sedangkan IRS cair yaitu saringan dari rumen yang telah dibuang pada proses kegiatan pemotongan. Pada penelitian sebelumnya, isi rumen sapi dimanfaatkan kembali menjadi pupuk organik cair dan kompos. Namun sayangnya belum adanya penelitian mengenai penggabungan rumen dengan cairan rumen. Menurut Masnun (2014) di dalam rumen ternak ruminansia (sapi,kerbau, kambing dan domba)terdapat populasi mikroba yang cukup banyak jumlahnya. Cairan rumen mengandung bakteri dan protozoa. Konsentrasi bakteri sekitar pangkat 9 setiap cc isi rumen, sedangkan protozoa bervariasi sekitar 10 pangkat 5- 10 pangkat 6 setiap cc isi rumen.

Limbah garam (bittern) adalah air sisakristalisasi yang sudah banyak mengandung garam-garam magnesium (pahit). Sehingga pada proses pembuatan garam air ini dibuang untuk mengurangi kadar $\mathrm{Mg}$ dalam hasil garam, meskipun masih dapat menghasilkan Kristal $\mathrm{NaCl}$ karena dengan penggunaan kembali bittern dapat menurunkan kualitas garam itu sendiri (Purbani,2011)

Bahan Dasar pembuatan pupuk organik cair adalah rumen sapi. Menurut Rinsema (1983) Magnesium memiliki peran penting pada tanaman karena sebagai unsur pertumbuhan hijau daun dan klorofil. Karena itu kekurangan megnesium mengganggu pertumbuhan hijau daun. Ia menyebabkan tanaman berwarna hijau pucat .Oleh karena itu, limbah garam digunakan untuk memperkaya kandungan unsur hara, terutama magnesium. Penelitian ini bertujuan untuk mencari komposisi penambahan limbah garam yang optimum diharapkan dapat meningkatkan kandungan unsur hara magnesium dalam pupuk cair dari rumen sapi. Sehingga penulis melakukan penelitian dengan judul Pengolahan Limbah Rumah Pemotongan Hewan (RPH) menjadi Pupuk Cair Yang Diperkaya Unsur Magnesium Yang Berasal Dari Limbah Garam (Bittern).

\section{METODOLOGI PENELITIAN}

\section{Lokasi Sampling dan Pengambilan Sampel}

Lokasi sampling dilakukan di Laboratorium Lingkungan Jurusan Teknik Lingkungan Universitas Diponegoro. Pengambilan sampel untuk pengujian unsur hara makro $\mathrm{C}, \mathrm{N}, \mathrm{P}, \mathrm{K}$, dan Mg dilakukan selama 3 kali yaitu pada hari ke-0, hari ke-7 dan hari ke-14. Untuk pengukuran suhu dan $\mathrm{pH}$ dilakukan setiap hari untuk memantau proses terjadinya fermentasi. Variasi penelitian sebagai berikut:

A1 = Padat:cair (100:0) + limbah garam 0\%

A2 = Padat:cair (100:0) + limbah garam 1\%

$A 3=$ Padat:cair (100:0)+ limbah garam 5\%

B1 = Padat:cair $(75: 25)+$ limbah garam $0 \%$

B2 = Padat:cair $(75: 25)+$ limbah garam 1\%

B3 $=$ Padat:cair $(75: 25)+$ limbah garam $5 \%$

C1 = Padat:cair (50:50) + limbah garam 0\%

C2 = Padat:cair (50:50) + limbah garam 1\%

C3 = Padat:cair (50:50) + limbah garam 5\%

D1 = Padat:cair $(25: 75)+$ limbah garam $0 \%$

D2 = Padat:cair (25:75) + limbah garam 1\%

D3 = Padat:cair (25:75) + limbah garam 5\%

$\mathrm{E} 1=$ Padat:cair $(0: 100)+$ limbah garam $0 \%$

$E 2=$ Padat:cair $(0: 100)+$ limbah garam $1 \%$

E3 $=$ Padat:cair $(0: 100)+$ limbah garam 5\%

\section{Teknik Pengumpulan Data}

1. Eksperimen, yaitu melakukan eksperimen/ percobaan dengan membuat pupuk cair dari rumen sapi yang ditambahkan dengan limbah garam, lalu menguji kandungan unsur hara makro C,N,P,K, dan Mg sebelum dan setelah fermentasi dan mengamati pengaruh penambahan limbah garam.

2. Observasi, yaitu melakukan observasi terhadap bahan-bahan yang diperlukan dalam penelitian seperti rumen sapi (cair dan padat) dan limbah garam.

3. Dokumentasi, yaitu merode pengamatan dengan cara mendokumentasikan penelitian dari awal hingga akhir dengan foto atau kamera digital

4. Studi Literatur, yaitu dengan mengkaji literatur-literatur berupa buku, laporanlaporan, penelitian-penelitian, dan jurnaljurnal terdahulu yang relevan

\section{Analisis CNPK dan Mg}

Uji Kandungan unsure hara makro CNPK pada pupuk cair dilakukan dengan acuan SNI 19-7030-2004. 
Tabel 1 Metode Pengujian Unsur Hara Makro

\begin{tabular}{|c|l|c|c|}
\hline No & Parameter & Satuan & $\begin{array}{c}\text { Metode } \\
\text { Analisis }\end{array}$ \\
\hline 1 & $\begin{array}{l}\text { C-Organik } \\
(\mathrm{C})\end{array}$ & $\%$ & $\begin{array}{c}\text { Spektrofotomet } \\
\text { rik }\end{array}$ \\
\hline 2 & $\begin{array}{l}\text { Nitrogen } \\
\text { Total (N) }\end{array}$ & $\%$ & $\begin{array}{c}\text { Spektrofotomet } \\
\text { rik }\end{array}$ \\
\hline 3 & Phosfor (P) & $\%$ & $\begin{array}{c}\text { Spektrofotomet } \\
\text { rik }\end{array}$ \\
\hline 4 & Kalium (K) & $\%$ & AAS \\
\hline
\end{tabular}

\section{HASIL DAN PEMBAHASAN}

\section{Konsentrasi C-Organik}

Kandungan bahan organik berperan penting dalam bidang pertanian. Karena bahan organik dapat mengatur berbagai sifat tanah, kemudian sebagai penyangga persediaan unsurunsur hara bagi tanaman, dan berpengaruh terhadap struktur tanah. Menurut Sutedjo (1999) bahan organik merupakan bahan baku dalam pembentukan jaringan tubuh tanaman, yang berada dalam bentuk $\mathrm{H}_{2} \mathrm{O}$ (air), $\mathrm{H}_{2} \mathrm{CO}_{3}$ (asam arang) dan $\mathrm{CO}_{2}$ dalam udara. Kualitas bahan organik sangat menentukan kecepatan proses dekomposisi dan mineralisasi bahan organik.

Kadar C-Organik hasil fermentasi dari cairan rumen sapi mengalami penurunan. COrganik awal pada saat uji pendahuluan sebesar $6,33 \%$ (padatan rumen) dan 6,02 \% (cairan rumen). Setelah mengalami proses fermentasi hasil C-organik pada media $A, B, C, D$, dan E berturut-turut rata rata sebesar 0,$84 ; 1,34 ; 1,23$ ; 1,16 dan $0,95 \%$.

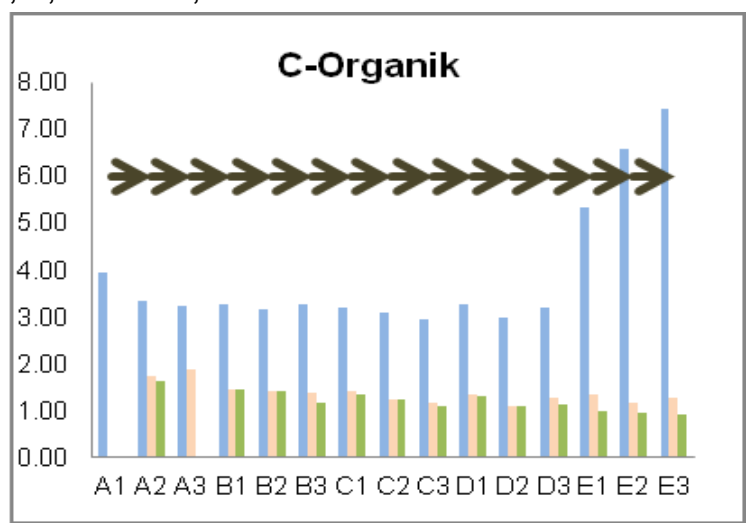

Gambar 1 Kandungan C-Organik Sebelum dan Setelah Fermentasi

Berdasarkan penelitian ini, kandungan COrganik pada pupuk belum memenuhi persyaratan teknis Permentan No 70 Tahun 2011 Tentang Pupuk Organik, Pupuk Hayati dan Pembenah Tanah. Kandungan C-Organik yang paling maksimum setelah fermentasi yaitu pada rasio 75:25 (serat kasar:cairan rumen) tanpa penambahan limbah garam sebesar $1,44 \%$.

\section{Konsentrasi Nitrogen Total}

Nitrogen merupakan unsur hara utama bagi pertumbuhan tanaman, yang ada pada umumnya sangat diperlukan untuk pembentukan atau pertumbuhan bagian-bagian vegetatif tanaman, seperti daun, batang, dan akar. Nitrogen atau Zat Lemas diserap oleh akar tanaman dalam bentuk $\begin{array}{llll}\mathrm{NO}_{3} & \text { (nitrat) dan } & \mathrm{NH}_{4}{ }^{+} & \text {(amonium). }\end{array}$ Kandungan Nitrogen dalam N-Total pada penelitian pupuk organik cair berbahan dasar limbah rumen tanpa atau dengan penambahan limbah garam ini belum memenuhi persyaratan teknis Permentan No .70/Permentan/SR.140/10/2011.

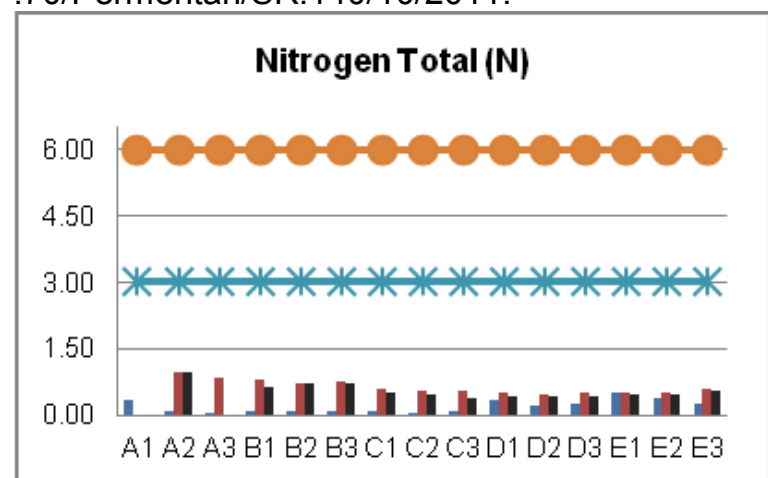

Gambar 2 Kandungan Nitrogen Total Sebelum dan Setelah Fermentasi

Pada Gambar 2 diketahui bahwa nilai kandungan Nitrogen pada pupuk organik cair yang berasal dari limbah rumen dengan penambahan limbah garam mengalami kenaikan setelah proses fermentasi pada hari ke-7 dan kemudian pada hari ke-14 mengalami penurunan. Rasio serat kasar $75 \%$ dengan cairan rumen $25 \%$ tanpa penambahan limbah garam sebelum fermentasi kandungan C-Organik sebesar 0,09\%setelah setelah fermentasi 7 hari menjadi $0,79 \%$,setelah fermentasi 14 hari menjadi $0,63 \%$ dan untuk rasio serat kasar $75 \%$ dengan cairan rumen $25 \%$ dengan penambahan limbah garam sebesar $5 \%$ yaitu dari 0,09\% pada hari ke-7 sebesar 0,78 dan pada hari ke-14 menjadi $0,71 \%$. Hal ini terjadi karena bakteri memecah kandungan Nitrogen yang terdapat dalam limbah garam sehingga kandungan nitrogen pada proses fermentasi meningkat, 
namun setelah itu bakteri menggunakan $\mathrm{N}$ untuk mensintesis protein (Indriani,2013). Pada akhir proses fermentasi, bakteri niktrifikasi mengubah amonia menjadi nitrat yang menyebabkan unsur nitrogen dalam fermentasi meningkat.

Kandungan Nitrogen yang paling maksimum setelah fermentasi yaitu pada rasio 75:25 (serat kasar:cairan rumen) dengan penambahan limbah garam sebesar $1 \%$ menjadi $0,73 \%$.

\section{Konsentrasi Fospor}

Fosfor terdapat dalam bentuk phitin, nuklein dan fosfatide, merupakan bagian dari protoplasma dan inti sel. Sebagai bagian dari inti sel sangat penting dalam pembelahan sel, demikian pula bagi perkembangan jaringan meristem. Fosfor diambil tanaman dalam bentuk $\mathrm{H}_{2} \mathrm{PO}_{4}^{-}$, dan $\mathrm{HPO}_{4}{ }^{-}$. Kesetimbangan ion-ion ini dalam larutan tanah dikendalikan oleh $\mathrm{pH}$ tanah. Serapan fosfat terbesar terjadi pada kisaran $\mathrm{pH}$ 4,0-8,0 dan di atas atau dibawah nilai ini akan menyusut. Pada kisaran $\mathrm{pH}$ itu larutan tanah lebih banyak mengandung ion-ion fosfat.

Kandungan Fospor dalam bentuk $\mathrm{P}_{2} \mathrm{O}_{5}$ pada penelitian pupuk organik cair berbahan dasar limbah rumen fermentasi hari ke-7 pada rasio 100:0, 75:25, dan 50:50 memenuhi persyaratan teknis Permentan No 70/Permentan/SR.140/10/ 2011.

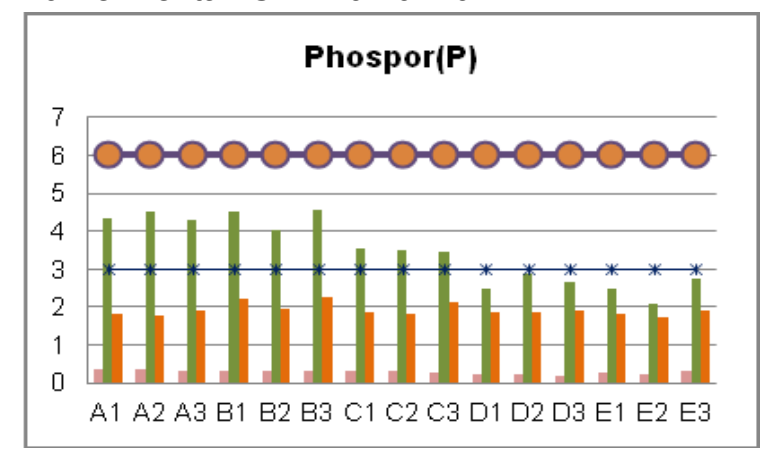

Gambar 3 Kandungan Fospor Sebelum dan Setelah Fermentasi

Nilai kandungan $\mathrm{P}_{2} \mathrm{O}_{5}$ pada pupuk organik cair berbahan dasar limbah rumen dengan penambahan limbah garam pada perbandingan serat kasar dengan cairan rumen sebanyak 75:25 lebih besar jika dibandingkan kandungan $\mathrm{P}_{2} \mathrm{O}_{5}$ pada pupuk organik cair tanpa penambahan limbah garam. Karena dengan perbandingan serat kasar sebanyak $25 \%$ dengan cairan rumen sebanyak $75 \%$ menghasilkan bahan organik yang cukup tinggi. Selain itu suhu yang relatif hangat menyebabkan ketersediaan fosfor akan meningkat karena perombakan bahan organik juga meningkat. Ketersediaan fosfor menipis apabila suhu rendah.

Berdasarkan penelitian dapat diketahui kandungan $\mathrm{P}_{2} \mathrm{O}_{5}$ paling maksimum setelah fermentasi yaitu pada rasio 75:25 (serat kasar:cairan rumen) dengan penambahan limbah garam sebesar $5 \%$ menjadi $2,243 \%$.

\section{Konsentrasi Kalium}

Kalium diserap dalam bentuk $\mathrm{K}^{+}$(terutama pada tanaman muda). Menurut penelitian, kalium banyak terdapat pada sel-sel muda atau bagian tanaman yang banyak mengandung protein. Unsur Kalium ini berguna untuk membentukan protein dan karbohidrat, mengeraskan jerami dan bagian kayu dari tanaman, meningkatkan resistensi tanaman terhadap penyakit, dan meningkatkan kualitas biji/buah (Sutedjo,1999).

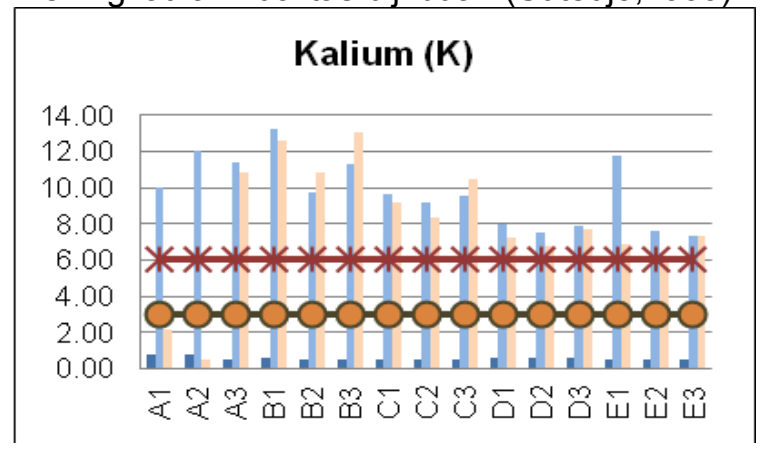

Gambar 4 Kandungan Kalium Sebelum dan Setelah Fermentasi

Kandungan Kalium dalam bentuk $\mathrm{K}_{2} \mathrm{Opada}$ penelitian pupuk organik cair berbahan dasar limbah rumen tanpa penambahan limbah garam ini belum memenuhi persyaratan teknis Permentan no 70/Permentan/SR.140/10/2011.

Semakin besar kandungan serat kasar rumen dengan campuran cairan rumen dapat menghasilkan kandungan $\mathrm{K}_{2} \mathrm{O}$ yang besar. Kandungan $\mathrm{K}_{2} \mathrm{O}$ pada hari ke-0 paling maksimum terdapat pada rasio 100:0 (serat kasar:cairan rumen) dengan penambahan limbah garam sebanyak $1 \%$ yaitu $0,76 \%$. Namun setelah proses fermentasi 14 hari pada rasio 100:0 mengalami penurunan sedangkan pada rasio 75:25 dengan penambahan limbah garam sebanyak $5 \%$ yang merupakan kandungan $\mathrm{K}_{2} \mathrm{O}$ paling optimum yaitu $1,305 \%$

Menurut Indriani (2013) hal ini terjadi karena hasil pelapukan melepas ion $\mathrm{K}^{+}$dari situs pertukaran kation dan dekomposisi bahan organik yang terlarut dalam pupuk organik cair 
berbahan dasar limbah rumen dengan atau tanpa penambahan limbah garam.

\section{Konsentrasi Magnesium}

Magnesium diserap oleh tanaman dalam bentuk $\mathrm{Mg}^{++}$, merupakan bagian dari klorofil. Kekurangan zat ini maka akibatnya adalah klorosis, gejala-gejalanya akan tampak pada permukaan dain sebelah bawah.Mg banyak terdapat dalam buah dan juga dalam tanah (Sutedjo, 1999).

Unsur Magnesium memiliki peran penting dalam pembentukan zat hijau daun, karbohidrat, lemak dan minyak serta berperan dalam transportasi fosfat di tanaman.Kekurangan unsur hara magnesium ini dapat menyebabkan daun tua pada tanaman sehingga tanaman mengalami klorosis dan tampak bercak-bercak berwarna coklat. Selain itu daun mengering dan seringkali langsung mati daya tumbuh biji lemah (Mulyani,2014).

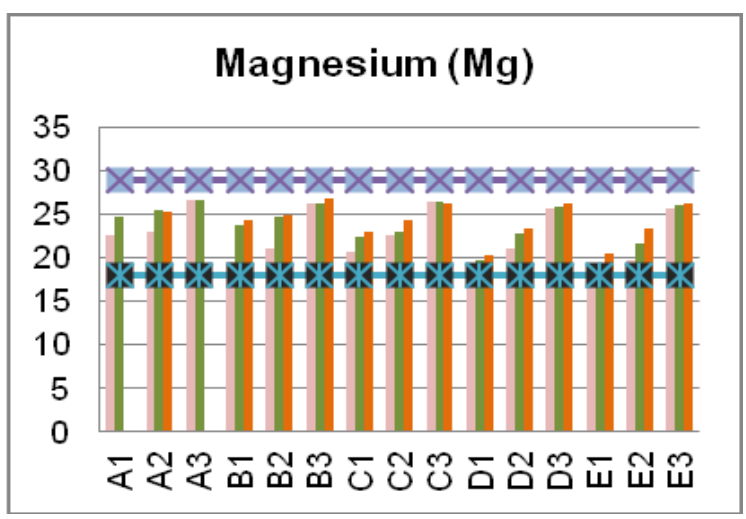

Gambar 5 Kandungan Magnesium Sebelum dan Setelah Fermentasi

Permentan

No

70/Permentan/SR.140/10/2011 tidak mengatur batas minimum maupun maksimum kadar Magnesium (Mg). Oleh karena itu, sebagai pembanding peneliti menggunakan kandungan Mg yang terdapat pada pupuk dolomit dan kiserit.

Penambahan limbah garam terhadap proses fermentasi ternyata mampu meningkatkan kandungan unsur magnesium dalam pupuk cair. Pada grafik di atas dapat dilihat bahwa lebih dominan mengalami peningkatan jika dibandingkan hari ke 0 . Kandungan $\mathrm{Mg}$ tertinggi terdapat pada C3 yaitu dengan perbandingan padatan : cairan limbah rumen sebanyak 50:50 dengan penambahan limbah garam sebanyak $5 \%$ dengan nilai Mg sebanyak $26,34 \%$.
Jika dibandingkan dengan kandungan Magnesium pada pupuk Magnesium yang dijual dipasaran, nilai Magnesium pada pupuk ini lebih besar, Selain itu, pupuk magnesium yang dijual di pasaran dalam bentuk granul maupun serbuk. Sedangkan pupuk yang dihasilkan setelah proses fermentasi ini merupakan pupuk organik cair, selain berasal dari bahan organik yang lebih aman jika diaplikasikan di tanaman, dan juga mudah diaplikasikan ke tanaman karena bentuknya yang cair.

\section{KESIMPULAN}

Berdasarkan penelitian proses pembuatan pupuk organik cair dari limbah rumen sapi dengan penambahan limbah garam yang telah dilakukan dapat disimpulkan sebagai berikut:

1. Kandungan C-Organik, Nitrogen, Fospor, Kalium dan Magnesium pada pupuk cair konsentrasi perbandingan serat kasar rumen dengan cairan rumen yang optimum terdapat pada rasio 0:100.

2. Pupuk cair dari limbah rumen dengan penambahan limbah garam ini belum memenuhi standar/syarat Permentan No. 70/PERMENTAN/SR.140/10/2011 tentang pupuk organik, pupuk hayati, dan pembenah tanah yaitu kadar C-Organik minimal $6 \%, \mathrm{~N}$ Total 3-6 \%, $\mathrm{P}_{2} \mathrm{O}_{5} 3-6 \%$, dan $\mathrm{K}_{2} \mathrm{O} 3-6 \%$

3. Penambahan limbah garam pada proses fermentasi pembuatan pupuk organik cair ini ternyata sangat mempengaruhi nilai unsur $\mathrm{K}_{2} \mathrm{O}$, dan $\mathrm{Mg}$. Sedangkan untuk unsur $\mathrm{C}$ Organik, $\mathrm{N}$-Total, dan $\mathrm{P}_{2} \mathrm{O}_{5}$ tidak terpengaruh dengan penambahan limbah garam

\section{SARAN}

1. Pupuk organik yang dihasilkan belum memenuhi Permentan No. 70/PERMENTAN/SR.140/10/2011 tentang pupuk organik, pupuk hayati, dan pembenah tanah. Pada penelitian selanjutnya sangat memungkinakan untuk dilakukan penambahan bahan-bahan yang dapat meningkatkan kandungan unsur hara makro $\mathrm{C}, \mathrm{N}, \mathrm{P}$, dan $\mathrm{K}$, sehingga nilai CNPK pada pupuk dapat memenuhi persyaratan.

2. Pengaruh pengadukan belum dilakukan pada roses fermentasi rumen sapi. 


\section{DAFTAR PUSTAKA}

Direktur Jendral Peternakan.2008. Seminar pada Acara Jambore dan Festival Karya Penyuluh Pertanian ke-2. Taman Cibodas, Cianjur, Jawa Barat

Djaja, Willyan. 2008. Langkah Jitu Membuat Kompos Dari Kotoran Ternak \& Sampah. Jakarta:Agromedia Pustaka

Hadisuwito, Sukamto. 2007. Membuat Pupuk Kompos Cair.Jakarta: Agromedia Pustaka.

Indriani, Fitri. 2013. Studi Pengaruh Penambahan Limbah Ikan Pada Pupuk Cair Dari Urin Sapi Terhadap Kandungan Unsur Hara Makro (CPNK). Skripsi. Program Sarjana Universitas Diponegoro

Masnun. 2014. Pemanfaatan Isi Rumen Sebagai Starter. http://www.bppjambi.info/dwnpublikasi. asp?id=131. 23 November 2014 (19.31).

Mulyani, Happy. 2014. Buku Ajar Kajian dan Aplikasi Optimasi Perancangan Model Pengomposan. Jakarta:TIM

Purbani, Dini.2001.Proses Pembentukan Kristalisasi Garam. Pusat Riset Wilayah Laut dan Sumberdaya Non Hayati. Departemen Kelautan dan Perikanan.

Republik Indonesia. 2011. Peraturan Menteri Pertanian Nomor 70/PERMENTAN/SR.140/10/2011 tentang Pupuk Organik, Pupuk Hayati Dan Pembenah Tanah. Sekretariat Negara. Jakarta.

Rinsema,WT..1983.Pupuk Dan Cara Pemupukan.Jakarta:Penebar Swadaya

Roihatin, Anis dan Arina Kartika Rizqi.2010. Pengolahan Air Limbah Rumah Pemotongan Hewan (RPH) Dengan Cara Elektrokoagulasi Aliran Kontinyu. http://eprints.undip.ac.id/1453/1/pdf.pdf. 23 November 2014 (19.07)

Sutedjo,Mulyani.1999. Pupuk Dan Cara Pemupukan.Jakarta:PT. Rineka Cipta 